\title{
THE LARGE VERTEBRATE REMAINS FROM BINDJAI TAMIENG (SUMATRA, INDONESIA)
}

\author{
Ben Jack Gruwier ${ }^{1,2}$ \\ ${ }^{l}$ Department of Anthropology, Durham University, South Road, Durham, United Kingdom \\ ${ }^{2}$ Department of Experimental Anatomy, Vrije Universiteit Brussel, Laarbeeklaan 103, Jette, Belgium \\ Email: Ben.Gruwier@hotmail.com
}

\begin{abstract}
Excavations in 1928 at the Binjai Tamieng shell midden in Northeast Sumatra brought to light a small assemblage of animal-and human remains that has never been studied in detail. The analysis of these Early Holocene finds suggests that besides mollusks and fish, a number of larger vertebrates played a role in the palaeoeconomy of the site. The composition of Binjai Tamieng has a somewhat similar signature to sites from Southern Thailand and Peninsular Malaysia. Testudine and artiodactyl remains are predominant in the vertebrate assemblage, while other species such as crocodile and a small cetacean were probably opportunistically hunted or scavenged. Animal bone was probably also used for the manufacturing of tools. Javan- and possibly Sumatran rhinoceros are present on the site. A number of human remains show traces of disarticulation and may be indicative of complex funerary rituals or cannibalism.
\end{abstract}

\section{INTRODUCTION}

This paper is concerned with a collection of vertebrate remains recovered from a shell midden in Northeast Sumatra. The site was excavated by the German Dr. H.M.E. Schürmann who worked between 1914 and 1930 as a geologist in the Dutch East Indies (now Indonesia) for the 'Bataafsche Petroleum Maatschappij' (Zwaan 1994). Although Schürmann mainly collected Precambrian rocks, in 1928 he took it upon himself to excavate one of two shell middens that were discovered in the previous years at the lower course of the Tamieng river in the Aceh province of Sumatra (Schürmann 1928). Although the exact location of the site is unknown, according to Schürmann (1928) it was situated somewhere along the old road between Kualasimpang and Seruway approximately $100 \mathrm{~m}$ south of the river and $15 \mathrm{~km}$ from its mouth (Figure 1).

An area of about $130 \mathrm{~km}$ along the Northeast coast of Sumatra is well known to have contained large numbers of shell middens associated with Hoabinhian lithic artifacts (Edwards MacKinnon 1991). Few of these sites have been systematically studied and most have now been lost to mining for lime by local communities and plantations (Tieng 2013). However, a similar shell midden was excavated in the 1930's by Van Stein Callenfels (1936) on the Malayan side of the Malacca strait and was recently re-studied by a team of Singaporean archaeologists (Tieng 2013). Most of the Sumatran shell middens of the so called "Hinai midden complex" were primarily composed of shells of the brackish bivalve mollusc Meretrix meretrix and were situated between ten and twenty kilometers from the current coast line (Edwards Mackinnon 1991). According to Brandt (1976) these sites resulted from the seasonal exploitation of estuarine resources. As sea levels only reached their current level around 5000 years ago, it is likely that many of these sites were originally situated much closer to the shoreline (Miksic 1977, Edwards Mackinnon 1991).

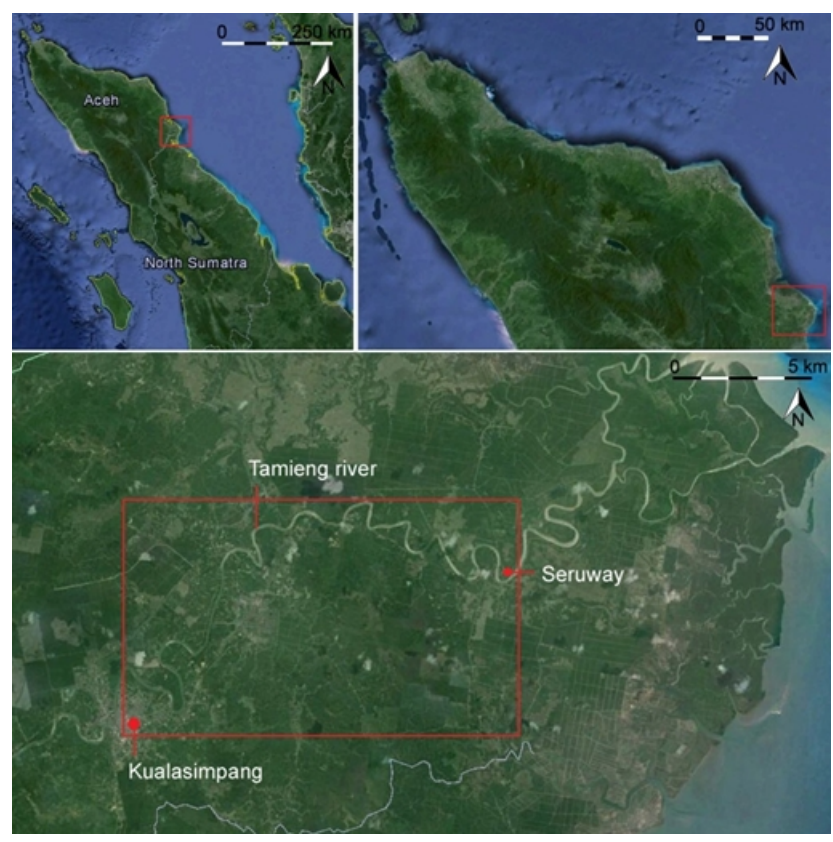

Figure 1: Approximate location of Bindjai Tamieng

Although part of the midden of Bindjai Tamieng was already dug away at the time of Schürmann's investigations (Schürmann 1928), it was probably completely destroyed before the end of the 1970's (Edwards Mackinnon 1991). A number of the remains collected by Schürmann were, however, preserved at Naturalis Center for Biodiver 


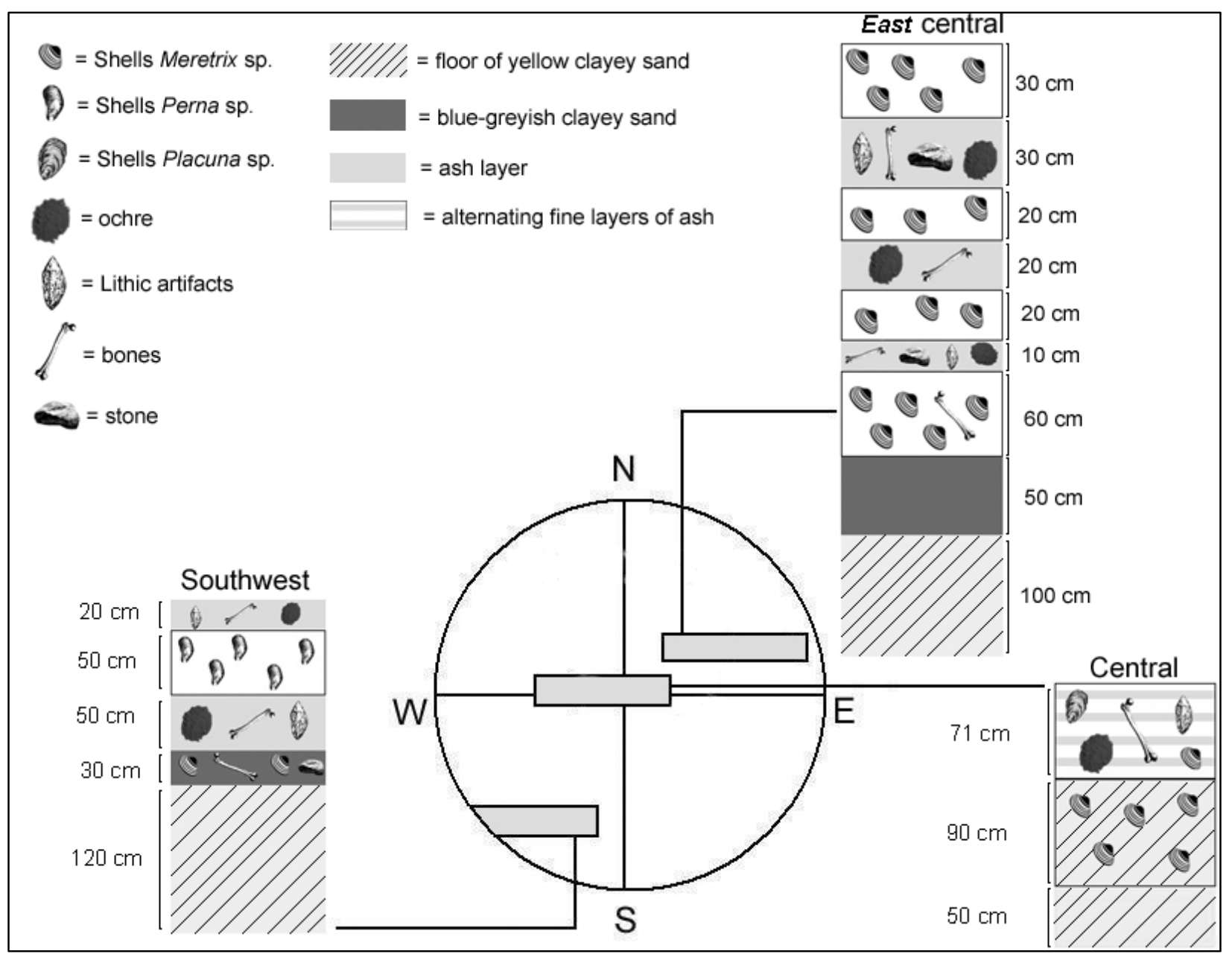

Figure 2: Visual scheme of the Bindjai Tamieng shell midden based on the descriptions by Schürmann (1928)

sity in Leiden (The Netherlands). Due to waterlogged conditions at Bindjai Tamieng, the preservation of organic remains is rather good (Edwards MacKinnon 1991) and as a result a number of animal- and human remains as well as botanical remains in the form of wood fragments were preserved (Schürmann 1928). It is the large vertebrate remains of this collection that are the topic of this study.

\section{TAPHONOMY AND ARCHAEOLOGICAL CONTEXT}

Schürmann (1928) excavated a number of trenches in order better to understand the stratigraphy of the midden that had a diameter of approximately $30 \mathrm{~m}$. A number of layers were identified based on the geological features of the site and the finds that were described in the different strata (Schürmann 1928). Precise details were not recorded and the collected remains were not labeled. The connection between the finds and the individual layers can therefore not be easily retraced. Schürmann (1928) described the stratigraphy in three different trenches: an east central-, a southwest- and a central trench. An attempt was made to summarize these descriptions into a visual scheme given below (Figure 2). The shell midden seems to have been accumu- lated on a floor of yellow clayey sand above which a number of alternating layers were present. Some of these layers were dominated by shells such as Meretrix sp. or Perna sp., others were described as ash layers containing ochre, animal- and human remains and lithic artifacts (Schürmann 1928). The absence of any ceramics should be noted.

According to Schürmann (1928), the site was of "young dilluvial" age and identical in material culture to the preceramic sites of Malaysia and Indo-China. This was based on the geological context, the predominance of sumatraliths alongside grinding stones and scrapers and on the presence of worked bone. Following the definition by Gorman (1970) (e.g. the presence of Sumatraliths together with iron oxide and the typical assemblage of animal remains) the site can most likely be considered as part of the Hoabinhian complex. However, because of the absence of a more precise chronology and the somewhat ambiguous nature of the term Hoabinhian (e.g. Matthews 1964, 1966, Gorman 1970), we consider this site as Terminal Pleistocene to Early Holocene. So far no attempt has been made at radiometrically dating the bones. 
The faunal remains are generally fragmentary but show indications that most were accumulated as a result of human activity. In the paper by Schürmann (1928) mention is made of a number of worked bones. The author described these bones as thick and probably belonging to very large mammals such as elephant or Rhinoceros. A distinction was made between four types of manipulation found on the worked fragments: reduction of thick bone to thin and sharp edges, polishing of the surface, polishing of the surface of fracture and colouring of the bones with ochre (Schürmann 1928). None of these artifacts were, however, preserved in the collection kept at Naturalis. Only a few fragments in the collection showed traces of bone working. It is therefore impossible to estimate the extent to which bone working was of importance on the site. Traces of butchery in the form of chopmarks and cutmarks were relatively common on the other hand. Several fragments were partially burned and indicative of exposure to open fire at relatively low temperatures.

\section{FAUNAL- AND HUMAN REMAINS}

Although the fauna from Bindej Tamieng was never published in detail, Dutch palaeontologist D.A. Hooijer at least briefly looked at it and wrote a short paper about the occurrence of Rhinoceros sondaicus on the site (Hooijer 1948a). In addition, he mentioned the presence of "elephants, bears, deer, dogs and swine" alongside "marine tortoises, fish and crabs". The present paper can therefore to some extent be seen as a reanalysis of the original findings by Hooijer (1948a) and Schürmann (1928).

Our own analysis indicated that the assemblage was composed of both vertebrates (mammals, fish and reptiles) and invertebrates (mollusks and crustaceans). Bird bones were absent from the collection. While the invertebrates and fish are mentioned here, the main focus of this study is the analysis of the large vertebrate fauna and especially the mammalian fauna. Even though the remains kept at Naturalis come from a shell midden, the shells themselves were not found in the museum repository. This may be because they were not initially collected in situ or possibly because they are currently kept at another unknown location. The mollusks were however already briefly described in the initial report on the site by Van der Meer Mohr and Oosting (in Schürmann 1928). Exact numbers were not given for the malacofauna, but an indication was provided of the relative abundance of each species (see Figure 2). The midden seems to have been mainly composed of Meretrix shells in addition to numbers of Perna sp. and Placuna placenta. A more detailed overview of the mollusks from Bindaj Tamieng can be found in the original paper (Schürmann 1928). Another invertebrate group that was well represented on the site is that of the crustaceans. More specifically 82 claw fragments of an unidentified species of crab (Brachyura indet.) were found.

Fish remains were quite common on the site. A total of 171 fish fragments were found at Binjaj Tamieng. A large number (82) of these fragments were identified as the remains of catfish (Siluriformes indet.). One dentary most likely belonged to a sea bream (Sparidae indet.) and a large vertebra was identified as a ray or shark (Elasmobranchii indet.). No further analysis of these remains was undertaken so far.

Reptiles were also well represented. In total 285 fragments were assigned to this class. The large majority of these (246) were plastron and carapace fragments of medium- to large sized soft shell turtles (Trionychidae), at least four of these were probably of the genus cf. Chitra. A number of these fragments showed clear traces of human manipulation. Four remains were partially burned indicating their exposure to open fire and one plastron fragment showed cutmarks on the ventral side. The 'marine tortoises' described by Hooijer (Hooijer in Schürmann 1928, Hooijer 1948a) are probably the above mentioned fragments. A further 16 fragments were placed in the Testudine order without a more precise identification. Other reptilian orders were represented by ten vertebrae of a monitor lizard (Varanus sp.), one indeterminate lizard (Lacertiliae indet.) and a femur of a large crocodile (Crocodilus cf. porosus). The latter also showed traces of burning and was probably exposed to fire in a similar way as the turtles.

A total of 230 fragments were classified as mammal bone, 70 of which could not be further identified to a lower taxonomic level. Two fragments were only assigned to a size class: large mammal or intermediate mammal. With the exception of dog, the majority of the mammals Hooijer mentioned in his paper (1948a) were also found in this study. In addition, some taxa were observed that were not previously described. An overview of the identified mammals is given in Table 1.

Table 1: Species list mammal remains Binjai Tamieng

\begin{tabular}{|c|c|}
\hline Taxa & NISP \\
\hline Sus scrofa/S. barbatus & 8 \\
\hline Bovidae indet. & 4 \\
\hline Cervus (Rusa) unicolor & 8 \\
\hline Muntiacus cf. muntjak & 3 \\
\hline Cervidae indet. & 1 \\
\hline Artiodactylae indet. & 20 \\
\hline Rhinoceros sondaicus & 1 \\
\hline Rhinocerotidae cf. Dicerorhinus sumatrensis & 1 \\
\hline Rhinocerotidae indet. & 1 \\
\hline Elephas maximus & 2 \\
\hline Helarctos malayanus & 1 \\
\hline Cercopithecidae indet. & 4 \\
\hline Homo sapiens & 97 \\
\hline Odontoceta indet. & 8 \\
\hline Large mammal & 1 \\
\hline Intermediate mammal & 1 \\
\hline Indeterminate mammal & 70 \\
\hline
\end{tabular}


A relatively large portion of the mammals (44 fragments) consisted of remains of different species of Artiodactylae. Twenty of these fragments could not be further identified but the remaining specimens were either placed in the cervid-, the suid- or the bovid family. All four identified fragments of bovids were ribs of a large sized species. Moreover, in one of the boxes containing the collection a note was found (perhaps written by Hooijer?) which mentioned 'Bubalus'. As this note was not found in direct association with the rib fragments, it is impossible to say whether it refers to these particular specimens or to some other, more diagnostic element that was later lost.

Cervids were a quite common element with 12 fragments. The presence of at least two different species was attested. Eight fragments could be attributed to a large deer, most likely sambar (Cervus (Rusa) unicolor). Traces of human modification were found on three of these specimens. On one of four antler fragments, a chopmark was found, possibly suggesting bone working. A naviculocuboid was partially burned and a tibia had cutmarks on the anterior and posterior shaft and around the distal articulation. The latter traces are probably the result of defleshing and/or disarticulation of the hindleg. The second deer species present at Binjai Tamieng was the muntjac (Muntiacus cf. munt$j a k)$. This species was represented by a single antler fragment, an upper second premolar and a tibia. No traces of human manipulation were found on these specimens.

Eight fragments were placed in the suid order. In the absence of more diagnostic elements, no distinction was made between the two species currently present in Sumatra: banded pig (Sus scrofa vittatus) and bearded pig (Sus barbatus). Adult- as well as sub-adult individuals were present in the assemblage. No traces of butchery of burning were found on the pig remains.

Perissodactyls are represented by a small number of rhinoceros bones. Hooijer (1948a) already convincingly argued the presence of Javan rhinoceros (Rhinoceros sondaicus) on the site, based on an upper second molar. In addition to this specimen however, two rhinoceros phalanges were found in the collection. One of these, a first phalanx of the central digit was compared to a small sample $(\mathrm{N}=4)$ of measurements on recent specimens of Javan- (Rhinoceros sondaicus) and Sumatran rhinoceros (Dicerorhinus sumatrensis) (Figure 3). Reference measurements came from the literature (Lestari 2009, Astriastita 2014), and from two specimens kept at the Museum of Vertebrate zoology at Berkeley (MVZ-mamm-208920) and the Zoological Museum of Kiel University (ZMK-1241). We followed the protocol of Sanisidro (2016) for measuring the phalanx. Although our limited sample size hinders a definite identification, the specimen from Binjai Tamieng appears to fall in the range of the smaller Sumatran rhinoceros (Dicerorhinus sumatrensis).

A conspicuous set of finds, that was not mentioned in the paper by Hooijer (1948a) are eight caudal vertebrae of a small toothed whale (Odontoceta indet.) of the size of bottlenose dolphin (Tursiops sp.) (Figure 4). It was unclear whether they belonged to the same individual. Species identification was unfortunately impossible in the absence of more diagnostic elements and due to the high diversity of species in this area. Interestingly, one of the vertebrae showed traces of cutmarks on the cranial side of the vertebral body, most likely indicating the disarticulation of the vertebral column.

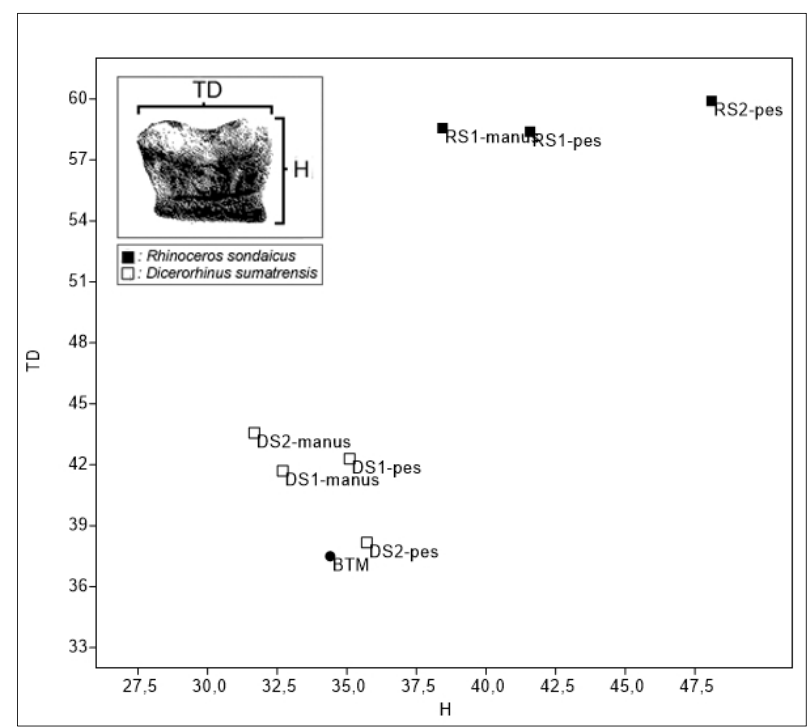

Figure 3: Measurements on rhinoceros first phalanx of central digit (pes and manus). $R S 1=R$. sondaicus individual $1, R S 2=R$. sondaicus individual $2, D S 1=D$. sumatrensis individual 1 , $D S 2=D$. sumatrensis individual 2 and BTM=Binjai Tamieng.

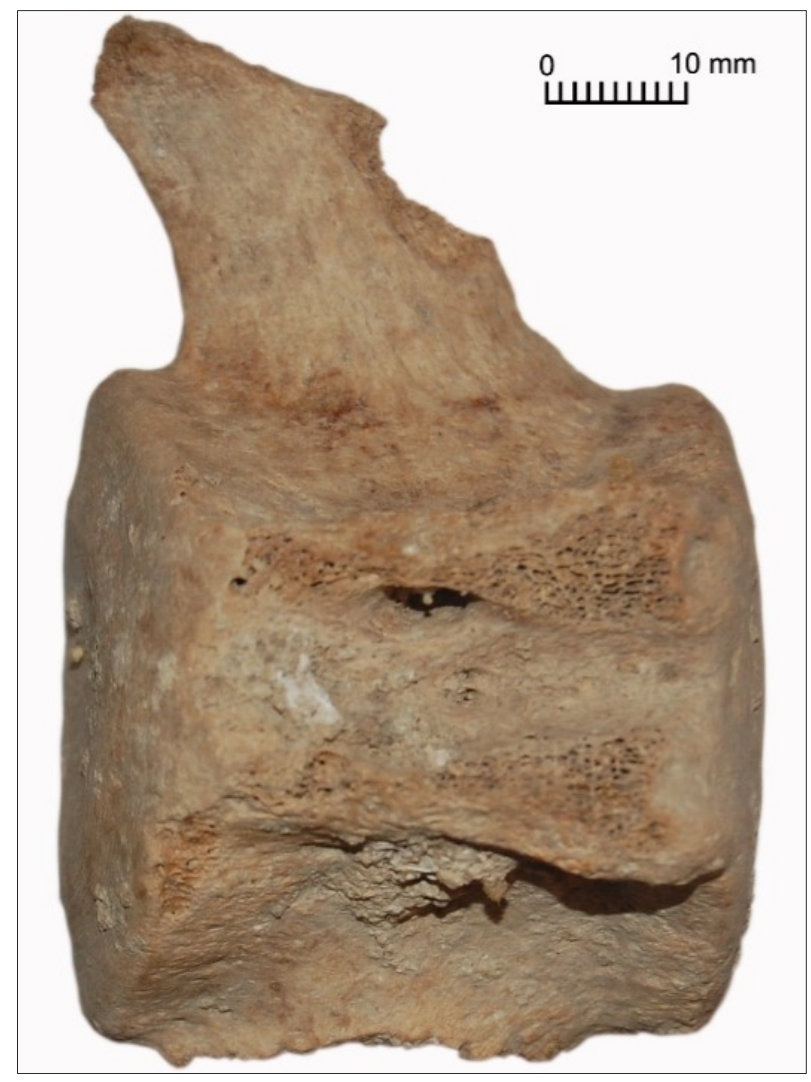

Figure 4: Caudal vertebra of a small toothed whale from Binjai Tamieng 
Remains of carnivores are represented by only one fragment. The worked "bear" tooth mentioned by both Hooijer (1948a) and Schürmann (1928) was found in the collection and identified here as an upper canine of a sun bear (Helarctos malayanus), the crown of which shows traces of bone working. The remains of two upper molars were identified as Asian elephant (Elephas maximus). No traces of human modification were found on the latter. Rodents or other microvertebrates were absent, but this is probably a consequence of taphonomic and collection bias.

A relatively large amount $(\mathrm{N}=97)$ of the mammal remains from Binjaj Tamieng consisted of badly preserved human remains belonging to at least five individuals $(\mathrm{MNI}=5)$. Hooijer briefly referred to these fragments in his paper on prehistoric man in Sumatra (1948b). Even though he (Hooijer 1948b) mentioned that Wastl (in von HeineGeldern 1945) studied the human bones from this site and concluded that they had "Papua-Melanesoid" characteristics, Hooijer himself considered the remains too fragmentary for any racial identification. Our reanalysis of the assemblage follows Hooijer in his more cautionary approach.

An interesting aspect about the human remains was however the presence of a number of cutmarks and shaving marks on some of the elements, indicating disarticulation and defleshing of at least some of the individuals. In one case shaving marks were found on the shaft of a humerus that represented most likely the results of defleshing the bone. On a further two femurs, cutmarks were found under the caput femoris on the cranial side of the bone, probably resulting from disarticulating the upper leg. One of these femurs also showed traces of red ochre, a pigment that was also found in some amounts on a few concretized chunks of small shell fragments that were part of the assemblage. No traces of anthropogenic manipulation were found on the skull fragments. An overview of the skeletal fragments represented at the site is presented in Table 2.

Table 2: Human elements represented at Binjai Tamieng

\begin{tabular}{ll}
\hline Element & NISP \\
\hline Cranium & 35 \\
Loose teeth & 1 \\
\hline & \\
\hline Vertebrae & 4 \\
Sacrum & 1 \\
Costae & 2 \\
\hline
\end{tabular}

\begin{tabular}{ll}
\hline Humerus & 10 \\
Ulna & 11 \\
Carpus & 1 \\
Metacarpals & 3 \\
Phalanges manus & 1 \\
\hline
\end{tabular}

Pelvis 4

$\begin{array}{ll}\text { Femur } & 6 \\ \text { Patella } & 1 \\ \text { Tibia } & 4 \\ \text { Calcaneus } & 1 \\ \text { Talus } & 2 \\ \text { Metatarsals } & 3 \\ \text { Phalanges pes } & 2\end{array}$

Unidentified long bones $\quad 5$

Total: 97

\section{DISCUSSION}

The composition of the animal remains from Binjai Tamieng is in many ways similar to that found in a number of Late Pleistocene/Early Holocene sites from Borneo and the Thai-Malay Peninsula. Although only a limited amount of fragments showed direct traces of butchery or burning, the majority of the animal remains can be interpreted as consumption refuse. Some fragments indicate that bone and antler also played a certain role as a raw material for the production of artifacts.

Hunter-gatherers at Binjai Tamieng must have targeted a diverse range of species, including mollusks, deer, pigs, fish and turtle. Some species such as crocodile and cetacean may have been hard to catch for practical- and safety reasons. It is doubtful they were systematically or even actively hunted, despite indications for consumption. They are more likely to represent opportunistic hunting or scavenging. Possibly the Asian elephant and sun bear also fall in this category. Nevertheless, large species such as the rhinoceros are thought to have been a relatively important aspect of the meat provisioning for hunter-gatherers at Laang Spean cave in Cambodia (Forestier et al. 2015). Perhaps this animal was also actively hunted in Sumatra, although other animals such as the artiodactyls seem to have played a more important role.

The Javan rhinoceros (Rhinoceros sondaicus) and Sumatran rhinoceros (Dicerorhinus sumatrensis) are known to have co-existed in a number of areas across Sundaland. Besides Binjai Tamieng, the two species were also found together at Gua Cha rockshelter in Malaysia (Hooijer 1962), at Niah cave in Borneo (Cranbrook \& Piper 2007) and in the Padang cave faunas from Southern Sumatra (Hooijer 1948a, de Vos 1983). Although the Sumatran species is absent from the Javan fossil record, the two forms must have commonly shared habitats in the past in Borneo, Sumatra and Peninsular Malaysia. The Sumatran rhinoceros always seems to have been the more common species. In the Sumatran cave assemblages $D$. sumatrensis was found to be four times more common than $R$. sondaicus, suggesting that the latter species was already rare in the area during the Pleistocene (Hooijer 1948a).

Non-human primates are conspicuously absent from the site with only four fragments of a not further identified cercopithecid. Similar sites from Borneo and Java, such as 
Madai (Harrison 1998), Niah (Piper et al. 2008) and Braholo (Amano et al. 2015) are often exceedingly rich in primate remains, implying this order was commonly targeted by prehistoric hunters, but this does not seem to have been the case at Binjai Tamieng. Orangutan (Pongo abelii), a species present in relatively large amounts in the Pleistocene cave faunas of Padang (de Vos 1983) and currently still found at less than $25 \mathrm{~km}$ from the site (Singleton et al. 2016), is absent from Binjai Tamieng. The reason for the rarity of primates at this site is unclear. Although it is tempting to explain this as a difference in human subsistence strategies, the small sample size and the possibility of collection bias make such an interpretation premature.

Both terrestrial and marine resources were exploited. The presence of a small cetacean supports the suspicion that the site must have been closer to the coast at the time of its accumulation (Schürmann 1928). The shell midden can probably best be described as an estuarine exploitation site. This is confirmed by the predominance of the brackish water bivalve Meretrix (lost from the collection now). In a similar early $20^{\text {th }}$ century shell midden on the Malayan side of the Malacca strait (Guar Kepah) the remains of mainly estuarine fish species were identified (van Stein Callenfels 1936). A probable sea bream and a ray or shark at our site are also indications that marine animals were targeted as well at Binjai Tamieng.

Even though the total sample size is small, the importance of (butchered) turtle remains and of artiodactyls relative to other mammals, reminds of broadly contemporary sites in Southern Thailand such as Lang Rongrien (Mudar and Anderson 2007) and Khao Toh Chong (Conrad et al. 2013). As many other sites in Thailand lack this abundance of turtles, the latter assemblages are thought to reflect specific adaptations of hunter gatherers to local environmental circumstances (Conrad et al. 2013). Keeping in mind that easily disintegrated turtle skeletons may give an overestimation of their importance in the faunal spectrum (Harrison 1998), such a scenario of specific adaptation to the local environment is also plausible for Binjai Tamieng and perhaps other sites of the Hinai midden complex.

Whether the exploitation of the area around the site happened on a seasonal base cannot be established, but perhaps the main attraction of Binjai Tamieng lay in its positioning along the ecotone between different habitats (coastal, riverine and forest). Some studies have indicated that sub-recent hunter-gatherers in the Philippines had a preference for exploiting ecotones, being especially rich in game or other resources (Peterson 1981). The presence of aquatic invertebrates alongside marine or estuarine fish and a rich diversity of terrestrial game must have made Binjai Tamieng an attractive location for prehistoric hunter-gatherers.

The interpretation of the substantial amount of human remains, a number of which show traces of butchery, presents a challenge. Hooijer (1948a) must have noticed these manipulations and interpreted them as evidence of cannibalism. More recent studies have demonstrated that the presence of disarticulated human remains in shell middens is not uncommon in Mesolithic and Neolithic sites in Europe and are probably part of complex funerary practices (Parker Pearson 2000, Hellewell \& Milner 2011). In analogy with ethnographic evidence such rituals are often related to a transitional phase where the deceased are no longer part of the living world but have not yet passed on to the hereafter (Hellewell \& Milner 2011). During this phase the dead are physically transformed from bodies to bones as a metaphor for their passage from the living- to the ancestral world (Metcalf \& Huntington 1991, Hellewell \& Milner 2011).

The most commonly encountered burial practice in prehistoric sites in Southeast Asia is primary inhumation in flexed or foetal position (Simanjuntak 2001, Barker et al. 2011, Lara et al. 2013, Piper 2016), but some exceptions do exist. Recent excavations at Ille (Palawan) have brought to light cremated human remains that exhibited similar traces of disarticulation and defleshing. According to the authors, the remains should be interpreted as the result of a complex funeral rite (Lara et al. 2013). Furthermore, isolated human remains with cutmarks have been found in the Holocene layers of Braholo cave in Java (Ingicco et al. 2011) and at Madai cave in Borneo. Harrison (1998) concluded that some charred and cut human remains found amongst the animal bones at Madai could be related to cannibalistic- or funereal practices. Several shell middens from Southern China and Vietnam have also given evidence that this type of sites often had a significance beyond the purely economic. Sites such as Ding Si Shan (Li et al. 2013), Con co Ngua (Oxenham 2006) and Da But (Bui 1991, Bellwood 2017) have large numbers of intentional burials associated with shell middens. In the light of these analogies and given the presence of red ochre on some of the bones it is tempting to explain the butchered human remains from Binjai Tamieng as the result of an elaborate funerary ritual. Nevertheless, the current lack of more data from Sumatra and the meager information available from the excavation of Binjai Tamieng, prevents us from excluding a more pragmatic interpretation of human consumption.

\section{CONCLUSION}

Few faunal assemblages from archaeological sites in $\mathrm{Su}-$ matra have been studied in detail. The analysis of Binjai Tamieng provides some long overdue insights into Early Holocene subsistence strategies in this area. Our findings suggest that Binjai Tamieng probably was an estuarine exploitation site where people made optimal use of available resources. Both aquatic- and terrestrial species were targeted at this site. Furthermore, our study of the human remains documents an unusual way of dealing with the deceased, involving the butchery of human carcasses. Such practices can probably be related to funeral rites or cannibalism. Further excavation and post-excavation analysis of the Hinnai shell middens in the area is required to better understand the subsistence economy and mortuary practices during this period in Sumatra. 


\section{ACKNOWLEDGEMENTS}

I wish to thank John de Vos, Tarek Oueslati and Eric Setyabudi for their comments and help with the identifications of the vertebrate fauna. My gratitude goes to Klaas Post for his help with the cetacean remains and to Lina Rosotta, Dana Lin and Chris Conroy for sharing measurements of rhinoceros bones. Thanks are also due to Natasja den Ouden who kindly allowed the author to study the finds from Binjai Tamieng as well as the rest of the Southeast Asian collections kept at Naturalis. The valuable and constructive comments provided by the anonymous reviewers of this paper are much appreciated.

\section{BIBLIOGRAPHY}

Amano, N., Moigne, A. M., Ingicco, T., Semah, F., Awe, R. D. \& Simanjuntak, T. 2015, Subsistence strategies and environment in Late Pleistocene-Early Holocene Eastern Java: Evidence from Braholo Cave, Quaternary International 416, pp. 46-63.

Asriastita, D. 2014, Karakteristik anatomi skelet kaki belakang badak Jawa (Rhinoceros sondaicus), Masters dissertation University Bogor.

Barker,G. Kloyd-Smith, L., Barton, H., Cole, F., Hunt, C., Piper, P.J., Rabett, R., Paz, V. \& Szabo, K. 2011, Foraging-farming transitions at the Niah Caves, Sarawak, Borneo, Antiquity 85,328 , pp. 492-509.

Bellwood, P. 2017, First islanders: prehistory and human migration in island Southeast Asia, John Wiley \& Sons, New York.

Brandt, R.W. 1976, The Hoabinhian of Sumatra: some remarks, Modern Quaternary Research in Southeast Asia 2, pp. 4952.

Bui, V. 1991, The Da But culture in the stone age of Vietnam, Bulletin of the Indo-Pacific Prehistory Association 10, pp. 127-131.

Conrad, C., Vlack, H. G. V., Marwick, B., Thengcharoenchalklt, C., Shoocongdej, R. \& Chaisuwan, B. 2013, Summary of vertebrate and molluscan assemblages excavated from Late-Pleistocene and Holocene deposits at Khao Toh Chong Rockshelter, Krabi, Thailand, The Thailand Natural History Museum Journal 7, pp. 1122.

Cranbrook, E. \& Piper, P. J. 2007, Short communication: the Javan rhinoceros Rhinoceros sondaicus in Borneo, The Raffles Bulletin of Zoology 55, 1, pp. 217-220.

Edwards Mackinnon, E. 1991, The Hoabinhian in the Wampu/Lau Biang Valley of Northeast Sumatra: An update, Bulletin of the Indo-Pacific Prehistory Association 10 , pp. $132-142$

Forestier, H., Sophady, H., Puaud, S., Celiberti, V., Frère, S., Zeitoun, V., Mourer-Chauviré, C., Mourer, R., Than, H. \& Billault, L. 2015, The Hoabinhian from Laang Spean Cave in its stratigraphic, chronological, typo-technological and environmental context (Cambodia, Battambang province), Journal of Archaeological Science: Reports 3, pp. 194-206.

Gorman, C. 1970, Excavations at Spirit Cave, North Thailand: some interim interpretations, Asian Perspectives 13, pp. 79-107.

Harrison, T. 1998, Vertebrate faunal remains from Madai caves (MAD 1/28), Sabah, East Malaysia, Indo-Pacific Prehistory Association Bulletin 17, pp. 85-92. von Heine-Geldern, R. 1945, Prehistoric Research in the Netherlands Indies, In: Honig, P. \& Verdoorn, F. (eds), Science and scientists in the Netherlands Indies, New York, pp. 129-167.

Hellewell, E. \& Milner, N. 2011, Burial practices at the Mesolithic-Neolithic transition in Britain: change or continuation?, Documenta Praehistorica 38, pp. 61-68.

Hooijer, D. 1948a, Rhinoceros sondaicus Desmarest from Kitchen middens of Bindjai Tamiang, North Sumatra, $\mathrm{Ge}$ ologie \& Mijnbouw 10, pp. 116-117.

Hooijer, D. 1948b, Prehistoric teeth of man and of the orang-utan from Central Sumatra, with notes on the fossil orang-utan from Java and Southern China, Zoologische Verhandelingen Museum Leiden 29, pp. 175-293.

Hooijer, D. 1962, Rhinoceros sondaicus desmarest from the Hoabinhian of Gua Cha rock shelter, Kelatan, Federation $\mathrm{Mu}$ seums Journal 7, pp. 23-24.

Ingicco, T., Detroit, F., Setiagama, K., Moigne, A.M., Gommery, D., Semah, A.M., Simanjuntak, H.T. \& Semah, F. 2011, Complex hunter-gatherers-monkey interactions in Southeast Asian archipelagos, Abstracts European Society for the Study of Human Evolution.

Lara, M., Paz, V., Lewis, H. \& Solheim II, W. 2013, Bone modifications in an Early Holocene cremation burial from Palawan, Philippines, International Journal of Osteoarchaeology 25, pp. 637-652.

Lestari, E.P. 2009, Anatomi skelet tungkai kaki badak sumatera (Dicerorhinus sumatrensis), Bogor.

Li, F.J., Wang, M.H., Fu, X.G., Dobney, K., Li, Z., Chen, B.Y., Yu, C. 2013, Dismembered Neolithic burials at the Ding Si Shan site in Guangxi, southern China, Antiquity 87, 337.

Matthews, J.M. 1964, The Hoabinhian in Southeast Asia and elsewhere, $\mathrm{PhD}$ dissertation Australian National University.

Matthews J.M. 1966, A Review of the 'Hoabinhian' in IndoChina, Asian Perspectives 9, pp. 86-95.

Metcalf, P \& Huntington, R. 1991, Celebrations of death: the anthropology of mortuary ritual, Cambridge University Press, Cambridge.

Miksic, J.N. 1977, Archaeology and paleogeography in the straits of Malacca, In: Hutterer, K. (ed.), Economic exchange and social interaction in Southeast Asia, University of Michigan papers on South-and Southeast Asia 13, pp. 155-176.

Mudar, K. \& Anderson, D. 2007, New evidence for Southeast Asian Pleistocene foraging economies: faunal remains from the early levels of Lang Rongrien rockshelter, Krabi, Thailand, Asian Perspectives 46, 2, pp. 298-334.

Oxenham, M. 2006, Biological responses to change in prehistoric Vietnam, Asian Perspectives 45, 2, pp.212-239.

Parker Pearson, M. 2000, Ancestors, bones and stones in Neolithic and Early Bronze age Britain and Ireland, In: Ritchie, A. (ed.), Neolithic Orkney in its European context, Mc Donald Institute for Archaeological Research, Cambridge, pp. 203-214.

Peterson, J. 1981, Game, Farming, and Interethnic Relations in Northeastern Luzon, Philippines, Human Ecology 9, pp. 122.

Piper, P.J. 2016, Human cultural, technological and adaptive changes from the end of the Pleistocene to the mid-Holocene in Southeast Asia, In: Oxenham, M. \& Buckleg, H.R. 
(eds), The routledge handbook of bioarchaeology in Southeast Asia and the Pacific, Taylor and Francis Group Ltd, New York, pp. 24-45.

Piper, P., Rabett, R. \& Bin Kurui, E. 2008,Using community, composition and structural variation in terminal Pleistocene vertebrate assemblages to identify human hunting behaviour at the Niah caves, Borneo, Indo-Pacific Prehistory Association Bulletin 28, pp. 88-98.

Sanisidro, O. 2016, Taxonomía, ecología y evolución de los rinocerontes (Rhinocerotidae, Perissodactyla) del Mioceno de la Península Ibérica, $\mathrm{PhD}$ dissertation Universidad Autonoma de Madrid.

Schürmann, H. 1928, Kjökkenmöddinger en Paleolithicum in Noord Sumatra, De Mijningenieur 12, pp. 1-19.

Simanjuntak, T. 2001, New light on the prehistory of the Southern Mountains of Java, Indo-Pacific Prehistory Association Bulletin 5, 21, pp. 152-156.

Singleton, I., Wich, S.A., Nowak, M. \& Usher, G. 2016, Pongo abelii. (errata version published in 2016), The IUCN Red List of Threatened Species 2016, Downloaded on 11 June 2017.

van Stein Callenfels, P. V. 1936, “An Excavation of three Kitchen Middens at Guak Kepah, Province Wellesley, Straits Settlements", Bulletin of the Raffles Museum Series B 1, pp. 27-37.

Tieng, F. S. 2013, The Guar Kepah Shell Middens: Evidence and Questions, Advancing Southeast Asian Archaeology 12, pp. 114-129.

de Vos, J. 1983, The Pongo faunas from Java and Sumatra and their significance for bio-stratigraphical and paleo-ecological interpretations, Proc. Koninklijke Nederlandse Akadademie van Wetenschappen 86, pp. 417-425.

Zwaan, J.C. 1994, The Dr H.M.E. Schürmann collection: Precambrian and other crystalline rocks and minerals, Scripta Geol. 107, pp. 27-41. 